JIIA, VOLUME 8 No. 2, MEI 2020

\title{
PENDAPATAN DAN TINGKAT KESEJAHTERAAN RUMAH TANGGA NELAYAN TRADISIONAL DI KECAMATAN TELUK PANDAN KABUPATEN PESAWARAN
}

\author{
(Income and Household Welfare Analyses of Traditional Fisherman in Teluk Pandan Subdisrict \\ Pesawaran Regency)
}

Marina Ulva, Fembriarti Erry Prasmatiwi, Eka Kasymir

Jurusan Agribisnis, Fakultas Pertanian, Universitas Lampung, Jl. Prof. Dr. Soemantri Brojonegoro No. 1 Bandar Lampung, 35145,e-mail: fembriarti.erry@fp.unila.ac.id

\begin{abstract}
This research is to analyze income obtained by traditional fishermen from fish catching, their household income, the level of welfare, and factors influencing the welfare level of traditional fishermen households in Teluk Pandan District. This study was conducted in Sukajaya Lempasing Village, Teluk Pandan District, Pesawaran Regency with a survey method. Respondents were 48 traditional fishermen who used netfish and were selected using simple random sampling method. Household income consists of on farm, off-farm, and non-farm. Household welfare level is analyzed by Central Agency on Statistics 2014 and the Sajogyo 1997 criteria. The factors influencing welfare are determined using binary logistic regression. The results showed that the income obtained by fishermen from fish catches in the western season was Rp6,570,375, in the eastem season was Rp25,452,214, and in the normal season was Rp15,229,771. The contribution of fish catches income (on farm) was 91.01 percent, the contribution of bussines income in the agricultural sector outside the fish catches (off farm) was 5.55 percent, and the contribution of business outside the agricultural sector (non-farm) was 3.60 percent. As many as 68.77percent of the traditional fishermen households are classified as unprosperous yet and 31.25 percent are prosperous based on Central agency on Statistics 2014 criteria. The factors influencing the welfare of traditional fishermen households were the level of education and income.
\end{abstract}

Key words: income, traditional fishermen, welfare.

\section{PENDAHULUAN}

Indonesia merupakan Negara Maritim atau Bahari, karena luas wilayah Indonesia didominasi dengan wilayah laut. Secara geografis Indonesia memiliki wilayah laut yang sangat luas yaitu sekitar dua pertiga wilayah dari negara Indonesia berupa lautan (Dinas Kelautan dan Perikanan Kota Bandar Lampung 2015). Luas wilayah laut Indonesia tersebut merupakan potensi alam yang dapat dimanfaatkan bagi pembangunan regional maupun nasional, salah satunya yaitu subsektor perikanan. Subsektor perikanan mempunyai peran penting dalam perekonomian Indonesia. Peran tersebut diantaranya yaitu, sebagai penyedia bahan pangan protein, penyedia lapangan pekerjaan dan memberikan kontribusi terhadap perolehan devisa suatu Negara (Mulyadi 2005).

Subsektor perikanan yang berpotensi dan dapat dimanfaatkan oleh rakyat Indonesia yakni perikanan tangkap. Hal ini menyebabkan sebagian besar masyarakat yang tinggal dan menempati daerah sekitar wilayah pesisir bermatapencaharian pada subsektor perikanan yaitu sebagai nelayan.
Berdasarkan teknologi peralatan tangkap yang digunakan, nelayan dapat dibedakan menjadi dua, yaitu, nelayan moderen dan nelayan tradisional. Nelayan tradisional merupakan nelayan yang dalam melakukan kegiatan produksi atau menangkap ikan menggunakan teknologi peralatan yang sederhana.

Provinsi Lampung memiliki luas laut sekitar $24.820 \mathrm{~km}^{2}$, dengan panjang garis pantai 1.105 $\mathrm{km}^{2}$ (termasuk beberapa pulau), dan memiliki 69 buah pulau. Salah satu kabupaten di Provinsi Lampung yang memiliki wilayah pesisir yang cukup luas dan potensial adalah Kabupaten Pesawaran. Dilihat dari luas perairan laut dan potensi yang cukup besar, sebagian besar masyarakat di Kabupaten Pesawaran bekerja sebagai nelayan. Salah satu kecamatan di Kabupaten Pesawaran yang memiliki jumlah produksi perikanan laut tangkap tertinggi pada tahun 2015 dibandingkan dengan kecamatan lain yaitu Kecamatan Teluk Pandan dengan jumlah produksi sebesar 4.597,89 ton per tahun (BPS Kabupaten Pesawaran 2015). 
Sebagian besar masyarakat di Kecamatan Teluk Pandan Kabupaten Pesawaran tergolong kedalam masyarakat miskin yaitu, sebanyak 4.641 kepala keluarga dengan persentase sebesar 45,13 persen (BPS Kabupaten Pesawaran 2015). Kemiskinan dan rendahnya derajat kesejahteraan sosial menimpa sebagian besar nelayan tradisional dan nelayan buruh yang merupakan kelompok sosial terbesar dalam populasi masyarakat nelayan (Kusnadi 2003). Kemiskinan terjadi karena belum terpenuhinya kebutuhan dasar (basic needs) secara minimal seperti kebutuhan akan pangan, sandang, papan, kesehatan dan pendidikan (Retnowati 2011). Belum terpenuhinya kebutuhan dasar ini bergantung terhadap tingkat pendapatan yang diperoleh nelayan tradisional.

Pendapatan rumah tangga nelayan akan menentukan tingkat kesejahteraan, akan tetapi sampai saat ini belum diketahui seberapa besar pendapatan rumah tangga dan kesejahteraan rumah tangga nelayan tradisional. Berdasarkan uraian pendahuluan, tujuan dari penelitian ini yaitu untuk mengetahui pendapatan yang diperoleh nelayan tradisional dari usaha perikanan tangkap, pendapatan rumah tangga nelayan tradisional, tingkat kesejahteraan rumah tangga nelayan tradisional dan faktor-faktor yang mempengaruhi tingkat kesejahteraan rumah tangga nelayan tradisional di Kecamatan Teluk Pandan, Kabupaten Pesawaran.

\section{METODE PENELITIAN}

Penelitian dilakukan di Kecamatan Teluk Pandan, Kabupaten Pesawaran. Penentuan lokasi dilakukan secara sengaja (purposive) dengan pertimbangan bahwa di Kecamatan Teluk Pandan memiliki produksi perikanan laut tangkap tertinggi di Kabupaten Pesawaran. Unit analisa dalam penelitian ini adalah rumah tangga nelayan tradisional di Desa Sukajaya Lempasing, Kecamatan Teluk Pandan, Kabupaten Pesawaran. Pengambilan data dilaksanakan pada bulan Januari hingga Maret 2018. Data yang dikumpulkan dalam penelitian ini terdiri dari data primer dan data sekunder. Responden dalam penelitian ini adalah nelayan tradisional yang menggunakan perahu motor tempel (perahu ketinting) dengan mesin yang ber PK kecil yang menggunakan alat tangkap yaitu jaring insang hanyut.

Pengambilan sampel dilakukan dengan menggunakan metode acak sederhana (simple random sampling) dengan pertimbangan bahwa responden di daerah penelitian cenderung homogen berdasarkan teknologi peralatan tangkap yang digunakan nelayan. Penentuan jumlah sampel mengacu pada Issac dan Michael dalam Sugiarto, Sunaryanto, dan Oetomo (2003), dimana jumlah populasi nelayan tradisional sebanyak 133 orang. Berdasarkan hasil perhitungan sampel tersebut diperoleh sebanyak 48 responden.

Untuk mengetahui pendapatan nelayan tradisional dari usaha perikanan tangkap menggunakan rumus menurut Shinta (2011) sebagai berikut:

$\pi=\mathrm{TR}-\mathrm{TC}=\mathrm{Y} \cdot \mathrm{Py}-(\mathrm{FC}+\mathrm{X} \cdot \mathrm{Px})$

Keterangan :

$$
\begin{array}{ll}
\pi & =\text { Pendapatan nelayan tradisional }(\mathrm{Rp}) \\
\mathrm{TR} & =\text { Total penerimaan dari kegiatan } \\
& \text { perikanan/Total revenue }(\mathrm{Rp}) \\
\mathrm{TC} & =\text { Total biaya/Total cost }(\mathrm{Rp}) \\
\mathrm{Py} & =\text { Harga jual/Price }(\mathrm{Rp} / \mathrm{Kg}) \\
\mathrm{Y} / \mathrm{Q} & =\text { Hasil tangkapan } / \text { Quantity }(\mathrm{Kg}) \\
\mathrm{FC} & =\text { Biaya tetap/Fixed cost }(\mathrm{Rp}) \\
\mathrm{X} & =\text { Faktor produksi }(\text { input })(\mathrm{satuan}) \\
\mathrm{Px} & =\text { Harga faktor produksi }(\mathrm{Rp})
\end{array}
$$

Lebih lanjut menurut Shinta (2011), untuk mengetahui apakah usaha perikanan tangkap menguntungkan atau tidak maka digunakanan analisis $R / C$ (Return Cost Ratio). Secara matematis dapat dilihat sebagai berikut:

$\mathrm{R} / \mathrm{C}=\frac{\mathrm{TR}}{\mathrm{TC}}$

Keterangan :

$\mathrm{R} / \mathrm{C}=$ Nisbah antara penerimaan dan biaya

TR = Total revenue (penerimaan total)

$\mathrm{TC} \quad=$ Total cost (biaya total)

Kriteria pada pengukuran tersebut adalah sebagai berikut :

1) Jika $R / C>1$, maka usaha perikanan tangkap yang diusahakan layak atau menguntungkan.

2) Jika $\mathrm{R} / \mathrm{C}<1$, maka usaha perikanan tangkap yang diusahakan tidak layak atau mengalami kerugian.

3) Jika $\mathrm{R} / \mathrm{C}=1$, maka usaha perikanan tangkap yang diusahakan berada dalam titik impas (BEP).

Untuk mengetahui pendapatan rumah tangga nelayan tradisional menggunakan rumus menurut Suriatiyah (2009) sebagai berikut: 


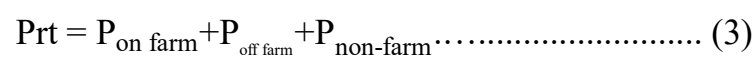

Keterangan :

Prt =Jumlah pendapatan rumah tangga nelayan tradisional

$\mathrm{P}$ on farm =Pendapatan dari usaha perikanan tangkap

$\mathrm{P}$ off farm =Pendapatan dari sektor pertanian di luar usaha perikanan tangkap

$\mathrm{P}$ non-farm =Pendapatan dari usaha di luar sektor pertanian

Untuk mengetahui tingkat kesejahteraan rumah tangga nelayan tradisional yaitu diukur berdasarkan kriteria menurut Sajogyo tahun 1997, dimana tingkat kesejahteraan rumah tangga dapat dilihat berdasarkan pengeluaran pangan dan pengeluaran non pangan rumah tangga dalam satu tahun dibagi dengan jumlah tanggungan keluarga. Guna mengukur tingkat kesejahteraan rumah tangga, dapat diukur berdasarkan pengeluaran rumah tangga perkapita pertahun yang terdiri dari pengeluaran pangan dan pengeluaran non pangan dibagi dengan harga beras perkilogram yang berlaku di daerah dan waktu penelitian. Besarnya pengeluaran rumah tangga perkapita pertahun yang diukur dengan setara harga atau nilai beras yang berlaku pada daerah setempat untuk daerah pedesaan adalah:

a) Rumah tangga sangat miskin $\quad:<180$ kilogram setara beras perkapita pertahun.

b) Rumah tangga miskin : :181-240 kilogram setara beras perkapita pertahun.

c) Rumah tangga nyaris miskin :241-320 kilogram setara beras perkapita pertahun.

d) Rumah tangga cukup $\quad:>480-960$ kilogram setara beras perkapita pertahun.

e) Rumah tangga hidup layak $\quad:>960$ kilogram setara beras perkapita pertahun.

Untuk mengetahui faktor-faktor yang mempengaruhi tingkat kesejahteraan rumah tangga nelayan tradisional menggunakan analisis logistic regression (logit). Logistic regression adalah regresi yang digunakan untuk menguji apakah probabilitas terjadinya variabel independen dapat diprediksi dengan variabel independen. Kategori paling dasar dari model logit menghasilkan binary values seperti angka nol dan angka satu sehingga sering disebut binary logistic (Ariefianto 2012). Angka nol menunjukkan rumah tangga belum sejahtera, sedangkan angka satu menunjukkan rumah tangga sejahtera. Bentuk persamaan model logit yang digunakan adalah :

$$
\begin{array}{r}
Z_{i}=\operatorname{Ln}\left[\frac{P_{i}}{1-P_{i}}\right]=\alpha+\beta_{1} X_{i}+\beta_{2} X_{2}+\beta_{3} X_{3} \\
+\beta_{4} X_{4}+\beta_{5} X_{5}+\ldots \ldots \ldots \ldots \ldots \ldots \ldots \ldots(4)
\end{array}
$$

\begin{tabular}{|c|c|}
\hline $\mathrm{Zi}$ & $\begin{array}{l}\text { =Peluang rumah tangga nelayan } \\
\text { tradisional untuk sejahtera, } \\
\text { dimana: }\end{array}$ \\
\hline & $\begin{aligned}= & \text { Probabilitas } \mathrm{Pi}=\mathrm{P}(\mathrm{Y}=0) \text { jika } \\
& \text { rumah tangga nelayan tradisional }\end{aligned}$ \\
\hline & $\begin{array}{l}\text { belum sejahtera. Probabilitas } \\
\mathrm{Pi}=\mathrm{P}(\mathrm{Y}=1) \text { jika rumah tangga } \\
\text { nelayan tradisional sejahtera }\end{array}$ \\
\hline & $\begin{array}{l}=\text { Peluang anggota untuk sejahtera } \\
\text { bila Xi diketahui }\end{array}$ \\
\hline & $=$ Intersep $/$ Konstanta \\
\hline$\beta_{1}, \beta_{2}, \beta_{3,} \beta_{4}, \beta_{5}$ & $=$ Koefisien variabel bebas \\
\hline & $=$ Jumlah anggota keluarga \\
\hline & $=$ Usia kepala keluarga \\
\hline & $=$ Pengalaman melaut \\
\hline & $=$ Tingkat pendidikan \\
\hline & $=$ Pendapatan rumah tangga \\
\hline & $=S t d$. Error \\
\hline
\end{tabular}

Keterangan :

Estimasi model logit dilakukan uji serentak yaitu menggunakan Likelihood Ratio (LR). Likelihood Ratio berfungsi untuk menguji apakah semua slope koefesien regresi variabel independen secara bersama-sama mempengaruhi variabel dependen. $\mathrm{H}_{0}$ ditolak jika Probability Likelihood Ratio $<\alpha$, dan $\mathrm{H}_{0}$ diterima jika Likelihood Ratio $>\alpha$. Selanjutnya dilakukan uji parsial (Z-Statistik) yaitu dengan menggunakan Wald Test. $\mathrm{H}_{0}$ ditolak jika Probability Wald $<\alpha$, dan $\mathrm{H}_{0}$ diterima jika Probability Wald $>\alpha$.

\section{HASIL DAN PEMBAHASAN}

\section{Karakteristik Responden}

Umur nelayan tradisional berkisar antara 36-51 tahun. Tingkat pendidikan nelayan tradisional tergolong cukup rendah, yaitu sebesar 62,50 persen hanya menamatkan sekolah dasar (SD). Pengalaman melaut nelayan tradisional rata-rata adalah 35 tahun. Nelayan tradisional memiliki jumlah tanggungan keluarga berkisar antara satu hingga delapan orang dengan rata-rata sebanyak lima orang. Untuk mencukupi kebutuhan rumah tangga yang masih jauh dari kecukupan, beberapa nelayan memiliki pekerjaan sampingan di luar dari pekerjaan utamanya yaitu sebagai pengrajin ikan fillet, pengrajin ikan asin, buruh nelayan, ojek, office boy, dan buruh non pertanian. 


\section{Usaha Perikanan Tangkap (On Farm)}

Nelayan tradisional di Kecamatan Teluk Pandan dalam melakukan usaha perikanan tangkap terdapat tiga musim yaitu, musim barat, musim timur, dan musim normal, dimana pada setiap musim berlangsung selama empat bulan dalam kurun waktu satu tahun dan pada setiap musim memiliki perbedaan dalam pola melaut. Perbedaan pola melaut tersebut terdiri dari perbedaan bulan melaut, waktu melaut, dan frekuensi melaut. Perbedaan pola melaut nelayan tradisional berdasarkan tiga musim di Kecamatan Teluk Pandan dapat dilihat pada Tabel 1.

Perbedaan pola melaut pada ketiga musim tersebut disebabkan oleh keadaan cuaca yang tidak menentu. Pada musim barat atau musim paceklik merupakan musim hujan, dimana kondisi laut sedang memburuk menyebabkan gelombang air laut besar hingga berukuran lebih dari satu meter. Hal tersebut berdampak pada aktivitas nelayan tradisional yang tidak memungkinkan untuk melakukan penangkapan ikan, sehingga menyebabkan frekuensi melaut pada musim barat yang lebih sedikit dibandingkan pada musim timur dan musim normal.

Pada musim timur nelayan tradisional sangat bersyukur karena musim timur merupakan musim kemarau, dimana kondisi laut sangat mendukung untuk melakukan aktivitas penangkapan ikan. Hasil tangkapan pada musim timur lebih banyak dibandingkan pada musim normal maupun musim barat.

\section{Pendapatan Usaha Perikanan Tangkap (On Farm)}

Nelayan tradisional dalam melakukan usaha perikanan tangkap (on farm) memerlukan input produksi untuk menunjang usahanya. Input produksi tersebut akan mempengaruhi besar kecilnya biaya produksi yang dikeluarkan oleh nelayan tradisional. Biaya produksi usaha perikanan tangkap meliputi biaya variabel dan biaya tetap. Biaya variabel terdiri dari biaya bahan bakar (solar), air mineral, konsumsi, balok es, garam, dan biaya gas. Biaya tetap dalam penelitian ini meliputi biaya tetap tunai dan biaya tetap diperhitungkan.

Biaya tetap tunai yaitu biaya tenaga kerja, biaya alat tangkap dan biaya perawatan perahu + jaring+ mesin. Biaya tetap diperhitungan adalah biaya penyusutan peralatan yang digunakan,
Tabel 1. Pola melaut nelayan tradisional berdasarkan musim barat, musim timur dan musim normal di Kecamatan Teluk Pandan, Kabupaten Pesawaran

\begin{tabular}{lccc}
\hline \multirow{2}{*}{ Pola Melaut } & \multicolumn{3}{c}{ Musim } \\
\cline { 2 - 4 } Bulan & Barat & Timur & Normal \\
\hline \multirow{2}{*}{ Oktober 2016 } & Februari 2017 & Juni 2017 \\
Waktu & $10.00-16.00$ & $16.00-05.00$ & $16.00-05.00$ \\
-Januari 2017 & - Mei 2017 & -September \\
Frekuensi & WIB & WIB & WIB \\
(per musim) & $80-89$ kali & $116-120$ & $96-100$ kali \\
Rata-Rata & & kali & \\
Frekuensi & 82 & 120 & 97 \\
\hline
\end{tabular}

dihitung berdasarkan umur ekonomis lebih dari satu tahun, peralatan tersebut yaitu perahu, mesin, drigen, galon, tabung gas, fiber, lampu emergency, tali tambang, peti, dan senter dengan rata-rata yaitu sebesar Rp9.134.138 pertahun. Rata-rata biaya, penerimaan dan pendapatan dari usaha perikanan tangkap persekali melaut nelayan tradisional pada setiap musim dapat dilihat pada Tabel 2.

Tabel 2. Pendapatan usaha perikanan tangkap nelayan tradisional persatu kali melaut pada ketiga musim

\begin{tabular}{|c|c|c|c|}
\hline Uraian & $\begin{array}{c}\text { Musim } \\
\text { Barat }\end{array}$ & $\begin{array}{l}\text { Musim } \\
\text { Timur }\end{array}$ & $\begin{array}{l}\text { Musim } \\
\text { Normal }\end{array}$ \\
\hline \multicolumn{4}{|l|}{ Per Satu Kali Melaut } \\
\hline 1. Penerimaan & 407.143 & 739.522 & 615.527 \\
\hline Ikan Semadar & 54.008 & 90.720 & 87.223 \\
\hline Ikan Belanak & 54.821 & 83.662 & 84.303 \\
\hline $\begin{array}{l}\text { Ikan Kacang- } \\
\text { kacangan }\end{array}$ & 66.310 & 52.650 & 70.779 \\
\hline Ikan Udo & 103.212 & 222.535 & 169.280 \\
\hline Ikan Taji-taji & 59.629 & 114.624 & 95.348 \\
\hline Ikan Kerapu & 69.164 & 175.330 & 108.594 \\
\hline \multicolumn{4}{|l|}{ 2. Biaya Produksi } \\
\hline $\begin{array}{l}\text { Biaya Variabel } \\
\text { (Tunai) }\end{array}$ & 247.418 & 313.766 & 302.720 \\
\hline \multicolumn{4}{|l|}{ Biaya Tetap } \\
\hline \multicolumn{4}{|l|}{ a. Biaya Tetap Tunai } \\
\hline 1) Tenaga Kerja & 80.127 & 212.102 & 157.008 \\
\hline $\begin{array}{l}\text { 2) Alat Tangkap } \\
\text { (Jaring) }\end{array}$ & 9.532 & 9.532 & 9.532 \\
\hline $\begin{array}{l}\text { 3) Pemeliharaan } \\
\text { perahu+mesin+alat } \\
\text { tangkap }\end{array}$ & 8.043 & 8.043 & 8.043 \\
\hline $\begin{array}{ll}\text { b. } & \text { Biaya Tetap } \\
& \text { Diperhitungkan }\end{array}$ & & & \\
\hline Biaya Penyusutan & 30.549 & 30.549 & 30.549 \\
\hline \multicolumn{4}{|l|}{ 3. Pendapatan } \\
\hline $\begin{array}{l}\text { Pendapatan Atas } \\
\text { Biaya Tunai }\end{array}$ & 62.032 & 196.079 & 138.224 \\
\hline $\begin{array}{l}\text { Pendapatan Atas } \\
\text { Biaya Total }\end{array}$ & 31.474 & 165.530 & 107.675 \\
\hline
\end{tabular}


Pada ketiga musim tersebut total biaya, penerimaan dan pendapatan tunai nelayan tradisional terbesar terjadi pada musim timur. Pendapatan tunai pada musim barat sebesar Rp62.032 musim timur sebesar Rp196.079 dan musim normal sebesar Rp138.224.

Nelayan tradisional di Kecamatan Teluk Pandan menggunakan tenaga kerja luar keluarga. Tenaga kerja atau anak buah kapal (ABK) dalam usaha perikanan tangkap yang dilakukan oleh nelayan tradisional berkisar antara dua sampai tiga orang dalam satu perahu. Biaya tenaga kerja yang dikeluarkan nelayan tradisional yaitu berdasarkan pembagian hasil sebesar 50 persen untuk juragan dan 50 persen untuk ABK. Penelitian ini sejalan dengan penelitian Putri, Lestari, dan Rangga (2016) tentang pengaruh status keanggotaan koperasi mitra karya bahari terhadap pendapatan rumah tangga dan ketahanan pangan nelayan di Pulau Pasaran Bandar Lampung pembagian hasil sebesar 50 persen.

Tabel 3. Pendapatan usaha perikanan tangkap permusim di Kecamatan Teluk Pandan

\begin{tabular}{|c|c|c|c|}
\hline Uraian & $\begin{array}{c}\text { Musim } \\
\text { Barat }\end{array}$ & $\begin{array}{l}\text { Musim } \\
\text { Timur }\end{array}$ & $\begin{array}{l}\text { Musim } \\
\text { Normal }\end{array}$ \\
\hline \multicolumn{4}{|l|}{ Per Musim } \\
\hline 1. Penerimaan & 33.496 .031 & 88.419 .083 & 59.936 .917 \\
\hline Ikan Semadar & 4.443 .250 & 10.846 .750 & 8.493 .333 \\
\hline Ikan Belanak & 4.510 .167 & 10.002 .875 & 8.208 .958 \\
\hline Ikan Kacang-kacangan & 5.455 .406 & 6.295 .000 & 6.892 .083 \\
\hline Ikan Udo & 8.491 .313 & 26.606 .854 & 16.483 .667 \\
\hline Ikan Taji-taji & 4.905 .688 & 13.704 .688 & 9.284 .500 \\
\hline Ikan Kerapu & 5.690 .208 & 20.962 .917 & 10.574 .375 \\
\hline \multicolumn{4}{|l|}{ 2. Biaya Produksi } \\
\hline $\begin{array}{l}\text { Biaya Variabel } \\
\text { (Tunai) }\end{array}$ & 20.355 .281 & 37.514 .656 & 29.477 .375 \\
\hline \multicolumn{4}{|l|}{ Biaya Tetap } \\
\hline \multicolumn{4}{|l|}{ a. Biaya Tetap Tunai } \\
\hline 1). Tenaga Kerja & 6.570 .375 & 25.452 .214 & 15.229 .771 \\
\hline $\begin{array}{l}\text { 2). Alat Tangkap } \\
\text { (Jaring) }\end{array}$ & 950.000 & 950.000 & 950.000 \\
\hline $\begin{array}{l}\text { 3). Pemeliharaan } \\
\text { perahu+mesin+alat } \\
\text { tangkap }\end{array}$ & 801.667 & 801.667 & 801.667 \\
\hline \multicolumn{4}{|l|}{$\begin{array}{l}\text { b. Biaya Tetap } \\
\text { Diperhitungkan }\end{array}$} \\
\hline Biaya Penyusutan & 3.044 .713 & 3.044 .713 & 3.044 .713 \\
\hline \multicolumn{4}{|l|}{ 3. Pendapatan } \\
\hline $\begin{array}{l}\text { Pendapatan Atas Biaya } \\
\text { Tunai }\end{array}$ & 6.570 .375 & 25.452 .214 & 15.229 .771 \\
\hline $\begin{array}{l}\text { Pendapatan Atas Biaya } \\
\text { Total }\end{array}$ & 1.773 .995 & 20.655 .834 & 10.433 .391 \\
\hline 4. $\quad$ R/C Ratio & & & \\
\hline $\mathrm{R} / \mathrm{C}$ Atas BiayaTunai & 1,24 & 1,40 & 1,34 \\
\hline $\mathrm{R} / \mathrm{C}$ Atas Biaya Total & 1,06 & 1,30 & 1,21 \\
\hline
\end{tabular}

Penerimaan dari usaha perikanan tangkap (on farm) diperoleh dari hasil tangkapan ikan dikalikan dengan harga jual ikan yang dinyatakan dalam satuan rupiah. Pada usaha perikanan tangkap terdapat tiga musim dalam satu tahun dimana pada setiap musim berlangsung selama empat bulan. Setiap musim memiliki jumlah hasil tangkapan ikan dan harga jual ikan yang berbeda-beda, namun pada jenis ikan yang diperoleh pada setiap musim sama.

Perbedaan tersebut dikarenakan keadaan cuaca yang berubah-ubah pada setiap tahun. Pada musim barat hasil tangkapan ikan sangat sedikit, akan tetapi pada musim timur hasil tangkapan ikan yang diperoleh nelayan tradisional sangat melimpah. Hal tersebut menyebabkan pada musim barat harga jual ikan lebih tinggi dibandingkan harga jual ikan pada musim timur. Jenis ikan yang diperoleh yaitu ikan semadar, ikan taji-taji, ikan kerapu, ikan kacang-kacangan, ikan udo, dan ikan belanak. Perbedaan jumlah hasil tangkapan dan harga jual ikan pada setiap musim akan menentukan pendapatan yang diperoleh nelayan tradisional.

Pendapatan pada musim timur lebih besar dibandingkan pada musim barat. Perbedaan pendapatan pada setiap musim tersebut disajikan pada Tabel 3. Berdasarkan Tabel 3 dapat dilihat bahwa besarnya $\mathrm{R} / \mathrm{C}$ atas biaya tunai maupun $\mathrm{R} / \mathrm{C}$ atas biaya total pada setiap musim yang diperoleh dari usaha perikanan tangkap nelayan tradisional yaitu lebih besar dari satu. Besarnya nisbah antara penerimaan dengan biaya tersebut menunjukkan bahwa usaha perikanan tangkap nelayan tradisioanl pada musim barat, musim timur dan musim normal layak untuk dilakukan atau memberikan keuntungan $(\mathrm{R} / \mathrm{C}>1)$.

\section{Pendapatan Rumah Tangga Nelayan Tradisional}

Pendapatan rumah tangga nelayan tradisional di Kecamatan Teluk Pandan, Kabupaten Pesawaran terdiri dari pendapatan dari usaha perikanan tangkap (on farm), pendapatan dari sektor pertanian di luar usaha perikanan tangkap (off farm), dan pendapatan di luar sektor pertanian (non-farm). Pendapatan yang diperoleh nelayan tradisional dari usaha perikanan tangkap, berasal dari penerimaan hasil tangkapan ikan dikurangi dengan total biaya yang dikeluarkan oleh nelayan tradisional. Rata-rata pendapatan rumah tangga nelayan tradisional pertahun dapat dilihat pada Tabel 4. 
Tabel 4. Rata-rata pendapatan rumah tangga nelayan tradisional pertahun di Kecamatan Teluk Pandan, Kabupaten Pesawaran

\begin{tabular}{lcc}
\hline $\begin{array}{l}\text { Pendapatan Rumah Tangga } \\
\text { Nelayan Tradisional }\end{array}$ & $\begin{array}{c}\text { Pendapatan } \\
\text { (Rp/thn) }\end{array}$ & $\%$ \\
\hline $\begin{array}{l}\text { Pendapatan dari usaha } \\
\text { perikanan tangkap (on farm) }\end{array}$ & 44.847 .359 & 91,01 \\
$\begin{array}{l}\text { Pendapatan dari usaha } \\
\text { di sektor pertanian di luar } \\
\text { perikanan tangkap }\end{array}$ & 2.736 .776 & 5,55 \\
$\begin{array}{l}\text { (off farm) } \\
\begin{array}{l}\text { Pendapatan dari usaha } \\
\text { di luar sektor pertanian }\end{array}\end{array}$ & \\
(non-farm) & 1.775 .000 & 3,60 \\
\hline Jumlah & 49.276 .526 & 100,00 \\
\hline
\end{tabular}

Rata-rata pendapatan rumah tangga nelayan tradisional di Kecamatan Teluk Pandan, Kabupaten Pesawaran yaitu sebesar Rp49.276.526 pertahun yang bersumber dari pendapatan on farm, off farm dan non-farm. Kontribusi pendapatan rumah tangga nelayan tradisional dari usaha perikanan tangkap (on farm) menyumbangkan jumlah yang sangat besar yaitu sebesar Rp44.847.359 pertahun atau sebesar $(91,01 \%)$. Hal ini menunjukkan bahwa sebagian besar pendapatan rumah tangga nelayan tradisional diperoleh dari sumber pekerjaan utamanya yaitu sebagai nelayan tradisional.

Hasil penelitian ini sejalan dengan penelitian Sudarso (2007) tentang tekanan kemisikinan struktural kemiskinan nelayan tradisional di perkotaan menyatakan alasan utama responden menekuni pekerjaan sebagai nelayan tradisional adalah karena tidak ada alternatif pekerjaan lain yang dapat dilakukan oleh nelayan tradisional. Kontribusi pendapatan rumah tangga dari sektor pertanian di luar usaha perikanan tangkap (off farm) berasal dari buruh nelayan, pengarajin ikan fillet dan pengrajin ikan asin yaitu sebesar Rp2.736.776 pertahun (5,55\%),dan dari kegiatan di luar sektor pertanian (non-farm) yang berasal dari buruh non pertanian, ojek dan office boy yaitu sebesar Rp1.775.000 pertahun (3,60\%).

Hasil penelitian ini selain sejalan dengan penelitian Sudarso (2007), penelitian ini sejalan dengan penelitian Fadilah, Abidin, dan Kalsum (2014), tentang pendapatan dan tingkat kesejahteraan rumah tangga nelayan obor di Kota Bandar Lampung, dimana hasil penelitian tersebut menunjukkan bahwa kontribusi pendapatan rumah tangga nelayan di Kota Bandar Lampung terbesar berasal dari pendapatan usaha perikanan tangkap (on farm).

\section{Analisis Tingkat Kesejahteraan Rumah Tangga Nelayan Tradisional}

Analisis tingkat kesejahteraan rumah tangga nelayan tradisional dalam penelitian ini menggunakan kriteria kesejahteraan menurut Sajogyo (1997), dimana dalam pengukuran tingkat kesejahteraan rumah tangga dilakukan melalui pendekatan pengeluaran konsumsi rumah tangga. Pengeluaran konsumsi rumah tangga tersebut terdiri dari pengeluaran untuk pangan dan pengeluaran untuk non pangan yang dihitung perkapita pertahun, yang diukur dengan standar harga beras perkilogram yang berlaku di tempat dan waktu penelitian. Proporsi pengeluaran pangan dan pengeluaran non pangan rumah tangga nelayan tradisional di Kecamatan Teluk Pandan dapat dilihat pada Tabel 5.

Tabel 5. Proporsi pengeluaran pangan dan non pangan rumah tangga nelayan tradisional di Kecamatan Teluk Pandan

\begin{tabular}{|c|c|c|c|c|}
\hline No & Keterangan & $\begin{array}{l}\text { Pengeluaran } \\
\text { perbulan }(\mathrm{Rp})\end{array}$ & $\begin{array}{l}\text { Pengeluaran } \\
\text { pertahun (Rp) }\end{array}$ & $\%$ \\
\hline \multicolumn{5}{|c|}{ Pangan } \\
\hline 1. & Padi-padian & 379.933 & 4.559 .200 & 13,48 \\
\hline 2. & $\begin{array}{l}\text { Non Beras } \\
\text { /Umbi-umbian }\end{array}$ & 104.167 & 1.250 .000 & 3,70 \\
\hline 3. & Lauk pauk & 237.753 & 2.853 .033 & 8,43 \\
\hline 4. & Sayur-sayuran & 238.097 & 2.857 .167 & 8,45 \\
\hline 5. & Buah-buahan & 56.692 & 680.300 & 2,01 \\
\hline 6. & Minyak goreng & 47.733 & 572.800 & 1,69 \\
\hline 7. & $\begin{array}{l}\text { Bumbu- } \\
\text { bumbuan }\end{array}$ & 97.533 & 1.170 .400 & 3,46 \\
\hline 8. & Minuman & 79.694 & 956.333 & 2,83 \\
\hline 9. & $\begin{array}{l}\text { Makanan } \\
\text { minuman } \\
\text { (jajanan) }\end{array}$ & 134.653 & 1.615 .833 & 4,78 \\
\hline 10 . & Lain-lain & 88.011 & 1.056 .133 & 3,12 \\
\hline & $\begin{array}{l}\text { Keperluan } \\
\text { bayi/balita }\end{array}$ & 35.969 & 431.633 & 1,28 \\
\hline & $\begin{array}{l}\text { Total } \\
\text { Pengeluaran } \\
\text { Pangan } \\
\end{array}$ & 1.500 .236 & 18.003 .833 & \\
\hline \multicolumn{5}{|c|}{ Non Pangan } \\
\hline 1. & Rokok & 257.500 & 3.090 .000 & 9,13 \\
\hline 2. & Bahan bakar & 233.594 & 1.118 .000 & 3,01 \\
\hline 3. & PAM & 49.000 & 762.400 & 2,25 \\
\hline 4. & Kesehatan & 222.612 & 2.587 .196 & 7,65 \\
\hline 5. & Pendidikan & 291.931 & 4.070 .415 & 12,03 \\
\hline 6. & $\begin{array}{l}\text { Sandang dan } \\
\text { papan }\end{array}$ & 77.736 & 883.854 & 2,61 \\
\hline 7. & $\begin{array}{l}\text { Dana sosial dan } \\
\text { sumbangan }\end{array}$ & 118.793 & 1.432 .196 & 4,23 \\
\hline 8. & Komunikasi & 63.600 & 739.250 & 2,19 \\
\hline & Trasnportasi & 3.800 & 321.600 & 0,95 \\
\hline & $\begin{array}{l}\text { Total } \\
\text { Pengeluaran } \\
\text { Non Pangan }\end{array}$ & 1.318 .566 & 15.822 .794 & \\
\hline & $\begin{array}{l}\text { al Pengeluaran } \\
\text { ngan dan Non } \\
\text { Pangan }\end{array}$ & 2.818 .802 & $33,826,627$ & 100,00 \\
\hline
\end{tabular}


Rata-rata pengeluaran total rumah tangga nelayan tradisional di Kecamatan Teluk Pandan dapat dilihat pada Tabel 5 adalah sebesar Rp33.825.627 pertahun, yang terdiri dari pengeluaran pangan sebesar Rp18.003.833 pertahun dimana pengeluaran terbanyak untuk padi-padian yaitu sebesar 13,48 persen dan pengeluaran non pangan sebesar Rp15.822.794 pertahun. Pengeluaran rumah tangga nelayan tradisional lebih besar untuk untuk kebutuhan pangan dibandingkan dengan kebutuhan non pangan. Hal ini menunjukkan bahwa nelayan tradisional lebih mengutamakan pemenuhan kebutuhan pangan dibandingkan pemenuhan kebutuhan non pangan.

Rata-rata pengeluaran rumah tangga perkapita pertahun di Kecamatan Teluk Pandan setara nilai beras sebesar Rp6.056.912 perkilogram. Berdasarkan kriteria yang telah ditetapkan oleh Sajogyo (1997), pengeluaran rumah tangga perkapita pertahun nelayan tradisional di Kecamatan Teluk Pandan berada pada kisaran 357 sampai dengan 854 kilogram nilai beras pertahun. Dengan demikian, rumah tangga nelayan tradisional berada pada kriteria nyaris miskin sebesar 64,67 persen dan sebesar 33,33 persen berada pada kriteria cukup.

\section{Faktor-Faktor yang Mempengaruhi Tingkat Kesejahteraan Rumah Tangga Nelayan Tradisional di Kecamatan Teluk Pandan}

Hasil regresi binary logit faktor-faktor yang mempengaruhi tingkat kesejahteraan rumah tangga nelayan tradisional dapat dilihat pada Tabel 6 bahwa Mc Fadden R-squared yang diperoleh dari hasil analisis logistic regression (logit) yaitu sebesar 0,5161. Hal ini menunjukkan bahwa 51,61 persen variabel independen (peluang rumah tangga untuk sejahtera) dapat dijelaskan oleh variabel dependen (jumlah anggota keluarga, usia, pengalaman melaut, tingkat pendidikan dan pendapatan rumah tangga), sedangkan sisanya sebesar 48,39 dijelaskan oleh variabel lain yang tidak dimasukkan kedalam model.

Pengaruh variabel independen terhadap variabel dependen secara bersama-sama dapat diketahui dengan menggunakan uji LR Statistik. Nilai LR Statistik yaitu sebesar 30,77 dengan probabilitas LR Statistik sebesar $0,0000<0,01$ yang artinya variabel jumlah anggota keluarga, usia kepala keluarga, pengalaman melaut, tingkat pendidikan dan pendapatan rumah tangga nelayan tradisional secara bersama-sama berpengaruh terhadap peluang rumah tangga nelayan tradisional untuk sejahtera pada tingkat kepercayaan 99 persen.

Variabel tingkat pendidikan memiliki nilai probability sebesar 0,0262 . Nilai tersebut lebih kecil dari 0,05 persen (taraf kepercayaan 95\%), yang menunjukkan bahwa faktor tingkat pendidikan berpengaruh nyata terhadap peluang rumah tangga nelayan tradisional untuk sejahtera. Variabel pendapatan rumah tangga nelayan tradisional memiliki nilai probability sebesar 0,0103 . Nilai tersebut lebih kecil dari 0,05 persen (taraf kepercayaan 95\%), sehingga faktor pendapatan rumah tangga nelayan tradisional berpengaruh nyata terhadap peluang rumah tangga nelayan tradisional untuk sejahtera.

Variabel pengalaman melaut dan variabel usia kepala keluarga, memiliki nilai probability yang berbeda, dimana nilai probability variabel pengalaman melaut sebesar 0,8611 dan nilai probability variabel jumlah anggota keluarga yaitu sebesar 0,4148 yang artinya variabel pengalaman melaut dan variabel usia kepala keluarga tidak berpengaruh nyata terhadap peluang rumah tangga

Tabel 6. Hasil regresi binary logit faktor-faktor yang mempengaruhi kesejahteraan rumah tangga nelayan tradisional di Kecamatan Teluk Pandan, Kabupaten Pesawaran

\begin{tabular}{lrrrc}
\hline \multicolumn{1}{c}{ Variable } & Coefficient & Z-Statistic & \multicolumn{1}{c}{ Prob } & Odds Ratio \\
\hline Constant & $-22,39373$ & $-3,0312$ & 0,0024 & 1,8816 \\
Jumlah anggota keluarga $\left(\mathrm{X}_{1}\right)$ & $-0,37140$ & $-0,8155$ & 0,4148 & 0,6897 \\
Usia kepala keluarga $\left(\mathrm{X}_{2}\right)$ & 0,19048 & 0,6303 & 0,5285 & 1,2098 \\
Pengalaman melaut $\left(\mathrm{X}_{3}\right)$ & $-0,05384$ & $-0,1749$ & 0,8611 & 0,9475 \\
Tingkat pendidikan $\left(\mathrm{X}_{4}\right)$ & $0,63962^{*}$ & 2,2232 & 0,0262 & 1,8957 \\
Pendapatan rumah tangga nelayan $\left(\mathrm{X}_{5}\right)$ & $2,53 \mathrm{E}-07^{* *}$ & 2,5658 & 0,0103 & 1,0000 \\
\hline Log likelihood & $-14,4260$ & \multicolumn{3}{|}{} \\
Restr. log likelihood & $-29,8121$ & Mc Fadden R-squared & 0,5161 \\
LR statistic & 30,7722 & Prob (LR statistic) & 0,0000 \\
\hline
\end{tabular}

Keterangan:

$*$

: Signifikan pada 98 persen

: Signifikan pada 99 persen 
nelayan tradisional untuk sejahtera. Penelitian ini sejalan dengan penelitian Viyana (2015) tentang tingkat kesejahteraan rumah tangga nelayan kecil di Kabupaten Indramayu, dimana hasil penelitian tersebut menunjukkan bahwa salah satu faktor yang berpengaruh signifikan terhadap tingkat kesejahteraan rumah tangga nelayan yang sama pada penelitian ini adalah tingkat pendidikan. Faktor lain seperti usia nelayan, dan pengalaman melaut berpengaruh tidak signifikan terhadap tingkat kesejahteraan rumah tangga.

\section{KESIMPULAN}

Pendapatan yang diperoleh nelayan dari usaha perikanan tangkap pada musim barat sebesar Rp6.570.375, musim timur sebesar Rp25.452.214 dan musim normal sebesar Rp15.229.771. Kontribusi pendapatan usaha perikanan tangkap (on farm) sebesar 91,01 persen dari pendapatan rumah tangga nelayan tradisional, dan kontribusi pendapatan dari sektor pertanian di luar usaha perikanan tangkap (off farm) sebesar 5,55 persen serta kontribusi pendapatan dari usaha di luar sektor pertanian (non-farm) sebesar 3,60 persen. Tingkat Kesejahteraan rumah tangga nelayan tradisional yang tergolong kedalam rumah tangga belum sejahtera sebesar 68,77 persen dan rumah tangga yang tergolong kedalam rumah tangga sejahtera.sebesar 31,25 persen. Faktor-faktor yang mempengaruhi tingkat kesejahteraan rumah tangga nelayan tradisional adalah tingkat pendidikan dan pendapatan rumah tangga nelayan tradisional.

\section{DAFTAR PUS TAKA}

Ariefianto MD. 2012. Ekonometrika. Erlangga. Jakarta.

BPS [Badan Pusat Statistik] Kabupaten Pesawaran. 2015. Produksi Ikan di Kecamatan Teluk Pandan dalam Angka 2015. Badan Pusat Statistik Kabupaten Pesawaran. Gedong Tataan. https://pesawarankab.bps.go.id. [15 September 2017].

2015. Pendapatan Rumah Tangga Usaha Perikanan 2015. Badan Pusat Statistik Kabupaten Pesawaran. Lampung. https://pesawarankab.bps.go.id. [15 September 2018].
Dinas Kelautan dan Perikanan Kota Bandar Lampung. 2015. Laporan Hasil Pendataan Nelayan di Wilayah Pesisir Kota Bandar Lampung. Dinas Kelautan dan Perikanan Kota Bandar Lampung. Bandar Lampung.

Fadilah, Abidin Z, dan Kalsum U. 2014. Analisis pendapatan dan tingkat kemiskinan rumah tangga nelayan obor di Kota Bandar Lampung. JIIA, 2 (1): 71-76. https://media. neliti.com/media/publications/100881. [15 September 2018].

Kusnadi. 2003. Akar Kemiskinan Nelayan. PT Ikis Pelangi Aksara. Yogyakarta.

Mulyadi. 2005. Ekonomi Kelautan. Raja Grafindo Persada. Jakarta.

Putri AP, Lestari DAH, dan Rangga KK. 2016. Pengaruh status keanggotaan koperasi mitra karya bahari terhadap pendapatan rumah tangga dan ketahanan pangan nelayan di Pulau Pasaran Bandar Lampung. JIIA, 4 (2): 180-182. http://jurnal.fp.unila.ac.id/index. php/JIIA/article/view/1235/1132. [18 September 2018].

Retnowati E. 2011. Nelayan Indonesia dalam pusaran kemiskinan struktural perspektif sosial, ekonomi, dan hukum. Jurnal Perspektif, 16 (3): 149-159. http://jurnal perspektif.org/index.php//article/view/79. [22 Januari 2018].

Sajogyo T. 1997. Garis Kemiskinan dan Kebutuhan Minimum Pangan. LPSB-IPB. Bogor.

Shinta A. 2011. Ilmu Usahatani. UB Press. Jakarta.

Sudarso. 2007. Tekanan kemisikinan struktural kemiskinan nelayan tradisional di perkotaan. Jurnal Masyarakat Kebudayaan dan Politik, 20 (2): 13-28. https://e-journal.unair.ac.id/ MKP. [17 Januari 2019].

Sugiarto DS, Sunaryanto, dan Oetomo DS. 2003. Teknik Sampling. Gramedia Pustaka Utama. Jakarta.

Suriatiyah K. 2009. Ilmu Usahatani. Penebar Swadaya. Jakarta.

Viyana AT. 2015. Analisis tingkat kesejahteraan rumah tangga nelayan kecil di Kecamatan Indramayu Kabupaten Indramayu. Jurnal Agrista, 3 (4): 119-129. https://eprints.uns.ac. id/23142. [15 November 2017]. 